Ekonomi Sumberdaya Manusia

Nama: Andrea Anne Suharsono

KP: A

NRP: 130119001

\title{
Pentingnya Standar Kompetensi Untuk Mewujudkan Sumberdaya Manusia Berkualitas
}

Perkembangan teknologi yang sangat pesat disertai dengan adanya pertumbuhan ekonomi di Indonesia sangatlah berperan penting terutama bagi sektor industri. Dalam hal ini, diperlukan adanya daya saing yang bersifat global melalui pengembangan penerapan era industri 4.0. Konektivitas dan komunikasi serta pemahaman dalam menggunakan teknologi sangat dibutuhkan dan harus dimanfaatkan secara maksimal dalam rantai manufaktur. Revolusi industry 4.0 ini secara garis besar ditandai oleh adanya kemajuan teknologi serta kecerdasan yang bukan dari manusia

yang terintegrasi dengan sistem dan atau jaringan internet. Hal ini tentunya akan membutuhkan sumberdaya manusia yang unggul dan mampu mengikuti perkembangan teknologi sebagai modal untuk meningkatkan efisiensi dan efektivitas industry dalam hal produksi. Dari ini, akan muncul persaingan ketat di seluruh dunia dan tidak ada batasan antar usaha yang akan memengaruhi politik dan ekonomi suatu negara.

Untuk menunjang perkembangan revolusi industry 4.0, kinerja karyawan haruslah memenuhi standar perusahaan sehingga tidak menghambat jalannya kegiatan produksi namun sebaliknya menghasilkan kepuasan. Kinerja dan keterlibatan karyawan ini dipengaruhi oleh atasan, kebijakam, lingkungan kerja dan faktor-faktor lain. Lingkungan bisnis di berbagai sektor ini juga dapat berubah-ubah sehingga perusahaan harus beradaptasi agar tetap dapat bersaing. Selain itu, perusahaan hendaknya memberikan karyawannya kenyamanan dalam bekerja sehingga memungkinkan kemungkinan bersaing yang disesuaikan dengan kebutuhan lapangan kerja serta tuntutannya. Bekal bagi karyawan seperti adanya pelatihan terkait bidangnya untuk meningkatkan kualitas kerja dan bersosialisasi juga tidak kalah penting dalam hal ini. Lalu, sebagai apresiasi atas kinerja karyawannya, perusahaan dapat memberikan reward atau penghargaan sehingga dapat memotivasi karyawan dalam memperbaiki kinerjanya yang masih dinilai kurang dan meningkatkan daya saing. 
Perusahaan pada hakikatnya tidak dapat dijalankan tanpa sumberdaya manusia atau dengan kata lain bergantung pada manusia atau tenaga kerja sebagai salah satu modalnya. Tentunya, hubungan antar manusia pada perusahaan juga harus dijaga agar mampu meningkatkan produktivitas dan inovasi baik jangka pendek atau jangka panjang. Maka dari itu, perusahaan perlu mengetahui metode terbaik dalam penilaian kinerja karyawan baik secara vertikal atau horizontal dimana dapat menguntungkan pihak karyawan maupun pihak perusahaan. Tenaga kerja juga harus mampu memaknai pekerjaannya sehingga tidak hanya monoton mementingkan uang.

Di Indonesia sendiri, sumber daya manusia yang kompeten dan unggul untuk mengikuti era industry 4.0 ini. Dari sumberdaya manusia inilah perusahaan akan menuntut dan secara tidak langsung bergantung pada kecerdasan dan kemampuan kerja dari karyawannya. Kedepannya, orang-orang atau tenaga kerja dengan kemampuan mengoperasikan teknologi akan lebih dicari perusahaan dibandingkan tenaga kerja yang hanya memiliki kemampuan rata-rata di bidang tertentu. Tidak hanya kemampuan, namun karakter, cara memecahkan masalah dan kemampuan bekerja sama dalam tim serta berkomunikasi juga dinilai seiring dengan kinerjanya secara formal. Beberapa perusahaan di Indonesia yang melakukan peningkatan kualitas sumberdaya manusianya melalui berbagai program dan kegiatan antara lain PT Telkom, PT Pelindo IV, PT Astra dan masih banyak lagi. 